\title{
Lead concentrations in bones and feathers of the globally threatened Spanish imperial eagle
}

\author{
D.J. Pain ${ }^{a, *}$, A.A. Meharg ${ }^{b}$, M. Ferrer ${ }^{c}$, M. Taggart ${ }^{b}$, V. Penteriani ${ }^{c}$ \\ ${ }^{a}$ The Royal Society for the Protection of Birds - RSPB, The Lodge, Sandy, Bedfordshire SG19 2DL, UK \\ ${ }^{\mathrm{b}}$ School of Biological Sciences, University of Aberdeen, Aberdeen University, Cruickshank Building, St. Machar Drive, Aberdeen AB24 3UU, UK \\ ${ }^{\mathrm{c}}$ Department of Applied Biology, Estación Biológica de Doñana, Avda. María Luisa, Pabellón del Perú, 41013 Seville, Spain
}

\begin{abstract}
Raptors that consume game species may ingest lead fragments or shot embedded in their prey's flesh. Threatened Spanish imperial eagles Aquila adalberti feed on greylag geese in southern Spain in winter, and often ingest lead shot. We analysed bone and feather samples from 65 Spanish imperial eagle museum specimens collected between 1980 and 1999, to investigate the prevalence of elevated lead concentrations. Four of 34 birds (12\%) had very elevated bone lead concentrations. All four birds were young and the concentrations were outliers to the distribution, suggesting probable exposure to lead gunshot. Excluding these elevated lead outliers, bone lead concentrations were correlated with the bird's age at death. Three of 41 feathers (7\%) had elevated lead concentrations, indicative of high exposure during feather formation. When these outliers were omitted, feather lead concentration was correlated with the age of museum specimens, suggesting that a high proportion of feather lead was exogenous, deposited after specimen collection. Therefore, careful interpretation of feather lead concentrations is required to separate endogenous and exogenous lead. We discuss the potential significance of lead poisoning in Spanish imperial eagles and other raptors, and recommend measures for its reduction.
\end{abstract}

Keywords: Spanish imperial eagle; Lead; Shot; Bone; Feather

\section{Introduction}

Lead poisoning in waterfowl, through the ingestion of spent lead gunshot, has been well documented world-wide (Bellrose, 1959; Pain, 1995, 1996). In the USA, before a nationwide ban on the use of lead shot for waterfowl hunting (since the 1991/1992 season) lead poisoning resulted in the deaths of an estimated 1.6-2.4 million waterfowl annually (Bellrose, 1959; USFWS, 1986).

\footnotetext{
* Corresponding author. Tel.: +44-1767-680551; fax: +44-1767692365.

E-mail address: debbie.pain@rspb.org.uk (D.J. Pain).
}

Lead also affects many non-waterfowl species (Franson, 1996), a key group being Falconiformes. Lead poisoning in raptors affects both predators and scavengers, and the literature suggests that this almost always results from the ingestion of shot or bullet fragments along with flesh or body parts of game species (Clark and Scheuhammer, 2003). Many heavily hunted gamebirds, especially those of larger body size such as ducks or geese, are not killed outright by hunters, and carry spent shotgun pellets in their flesh (e.g., Scheuhammer and Norris, 1996). For example, several hundred bald eagles (Haliaeetus leucocephalus) have died from lead poisoning following shot ingestion (Franson, 1996), as well as several globally threatened species including the Californian condor Gymnogyps californianus in the USA (Wiemeyer 
et al., 1986, 1988), due to ingestion of bullet fragments whilst scavenging. Less is known of the incidence of lead poisoning in free-ranging raptors in Europe and Asia, although incidents of both shot ingestion, and subsequent lead poisoning, have been recorded in many species (Table 1).

Of European raptors subject to lead poisoning, the globally threatened Spanish imperial eagle Aquila adalberti (BirdLife International, 2000) is of greatest concern. The endemic Spanish imperial eagle is the most threatened bird of prey in Europe and one of the rarest raptors in the world (Ferrer, 2001), with a total population estimated at little more than 140 pairs (Ferrer, 2001). It has a low reproductive rate $(0.75$ chicks per pair per year), an immaturity period of $4-5$ years and an estimated longevity of 21-22 years maximum (Ferrer and Calderón, 1990). The population of Doñana National Park, southern Spain, remained stable during the period 1976-1992, with 15-16 pairs, subsequently declining to only seven pairs in 2002. Since 1991, more than $50 \%$ of mortality in birds from breeding pairs has been attributed to the illegal use of poison against generalist predators (typically foxes Vulpes vulpes ) (Ferrer et al., 2003). In Doñana, productivity of Spanish imperial eagles was low (Ferrer and Donázar, 1996), and declined dramatically in the late 1990s as adult mortality from poison increased (Ferrer et al., 2003). Whilst undoubtedly the major cause of recent mortality, the species may not only be threatened by illegal poisoning. Recent work has shown that $11 \%$ of egested eagle pellets collected between 1991 and 1996 contained lead gunshot (Mateo et al., 2001). However, whilst these results certainly show exposure to lead, not all exposure necessarily results in lead poisoning, and it is uncertain to what degree the eagles are currently suffering, and have historically suffered, from lead poisoning from gunshot ingestion.

Following absorption, lead is deposited in a range of tissues, primarily liver, kidney and bone. Whilst lead in liver and kidney has a turnover rate of weeks to months, lead is retained in bone for years, thus reflecting both acute and lifetime chronic exposure from all sources (Harrison and Laxen, 1981). Lead in bone has been physiologically incorporated over the lifetime of the bird, whereas feather lead comprises both that physiologically incorporated at the time of feather formation, and lead deposited on the feather surface between formation and moult or sampling (usually one to several years in the wild - longer with museum specimens). This makes physiologically incorporated or 'endogenous' lead difficult to identify in feathers (Dauwe et al., 2003), thus may limit their utility for monitoring lead absorption. However, feather sampling is simple and non-invasive, and could potentially be of use for future studies. Consequently, we compared lead concentrations in ten feather and bone samples to investigate both cor-

Table 1

Lead poisoning in free-ranging raptors

\begin{tabular}{|c|c|c|c|}
\hline Species & Threat status & Country & Reference \\
\hline Spanish imperial eagle, Aquila adelberti & Globally threatened 'Vulnerable' & Spain & Mateo et al. (2001); Hernández (1995) \\
\hline *Steller's sea eagle, Haliaeetus pelagicus & Globally threatened 'Vulnerable' & Japan & Kim et al. (1999); Kurosawa (2000) \\
\hline *White-tailed eagle, Haliaeetus albicilla & Near threatened & Japan, Germany & $\begin{array}{l}\text { Kim et al. (1999); Kurosawa (2000); } \\
\text { Kenntner et al. (2001) }\end{array}$ \\
\hline *Californian condor, Gymnogyps californianus & Globally threatened 'Critical' & USA & Wiemeyer et al. $(1986,1988)$ \\
\hline Griffon vulture, Gyps fulvus & & Spain & Mateo et al. (1997). \\
\hline Bald eagle, Haliaeetus leucocephelus & & USA and Canada & $\begin{array}{l}\text { Miller et al. (2001); } \\
\text { Wayland et al. (2003); } \\
\text { Pattee and Hennes (1983). }\end{array}$ \\
\hline Golden eagle, Aquila chrysaetus & & Canada, USA & $\begin{array}{l}\text { Wayland et al. (2003); } \\
\text { Bloom et al. (1989) }\end{array}$ \\
\hline Goshawk, Accipiter gentilis & & France, Germany & $\begin{array}{l}\text { Pain and Amiard-Triquet (1993); } \\
\text { Kenntner et al. (2003) }\end{array}$ \\
\hline Marsh harrier, Circus aeruginosus & & France, Spain & $\begin{array}{l}\text { Pain et al. }(1993,1997) \\
\text { Mateo et al. }(1999)\end{array}$ \\
\hline Red-tailed hawks, Buteo jamaicensis & & USA & Franson et al. (1996) \\
\hline Prairie falcon, Falco mexicanus & & USA & Benson et al. (1974) \\
\hline Peregrine, Falco peregrinus & & UK & Pain et al. (1995) \\
\hline Buzzard, Buteo buteo & & UK & Pain et al. (1995) \\
\hline Sparrowhawk, Accipiter nisus & & France & Pain and Amiard-Triquet (1993). \\
\hline Red kite, Milvus milvus & & Spain & Mateo et al. (2003) \\
\hline Eagle owl, Bubo bubo & & Spain & Mateo et al. (2003) \\
\hline Great-horned owl, Bubo virginianus & & Canada & Clark and Scheuhammer (2003) \\
\hline Red-tailed hawk, Buteo jamaicensis & & Canada & Clark and Scheuhammer (2003) \\
\hline
\end{tabular}

All species recorded have been diagnosed as lead-poisoned or as having tissue concentrations consistent with lead poisoning. When more than one reference is given for a species, some of these may refer to the presence of shot in regurgitated pellets. All records refer to lead shot ingestion except where starred ${ }^{*}$, when lead bullet fragments were involved. 
relations in $\mathrm{Pb}$ concentrations, and the proportion of samples showing elevated lead levels.

In this paper, we analyse lead concentrations in bones and feathers of Spanish imperial eagles collected between 1980 and 1999 and evaluate the extent to which this species may be subject to lead poisoning.

\section{Methods}

\subsection{Bone sampling}

Bone samples of approximately 2-4 g were extracted from the femurs of each of 34 Spanish imperial eagles from the scientific collection of Doñana Biological Station (Consejo Superior de Investigaciones Científicas). Birds were from Doñana $(\mathrm{n}=24)$, Malaga $(\mathrm{n}=1)$, Cadiz $(\mathrm{n}=4)$, Badajoz $(\mathrm{n}=1)$ Ciudad Real $(\mathrm{n}=1)$, and unknown origins $(n=3)$. All eagles died between 1980 and 1999 and dates of death were recorded. Exact ages were known for 24 birds, and ranged from chicks to an individual of 18 years old. Sex was recorded for 14 birds (10 females and 4 males), but only nine females and one male for which exact ages were known. Cause of death was known for 23 or $68 \%$ of birds; electrocution $(41 \%)$, illegal shooting $(6 \%)$, illegal poisoning $(15 \%)$, starvation $(6 \%)$, unknown/unrecorded $(32 \%)$.

\subsection{Feather sampling}

Samples of under-tail coverts were taken from 41 birds collected between 1940 and 1999. Samples were from Doñana (34), Cadiz (4), Sierra de Gredos (1), Seville (1) and Caceres (1). Exact ages were known for 17 of the birds.

Only 10 birds were available for sampling of both bone and feather (five females, five of unknown sex, collected from 1980 to 1999 ranging from pulli to 18 years old).

\subsection{Analytical methods}

Bones were dried to a constant weight. For $\mathrm{Pb}$ analysis, $0.2-0.3 \mathrm{~g}$ of the diaphysis without bone marrow was weighed and digested with $2.5 \mathrm{ml}$ of $70 \%$ nitric acid at room temperature for $12 \mathrm{~h}$. Two and a half milliliters of $30 \%$ hydrogen peroxide were then added and the temperature was gradually increased up to $160^{\circ} \mathrm{C}$ in $1 \mathrm{~h}$ and then held at that temperature for $4 \mathrm{~h}$. The digested samples were then diluted to a final volume of $10 \mathrm{ml}$ with deionized water and analyzed by graphite furnace-atomic absorption spectrometry on a Perkin-Elmer model 3300.

The detection limit was $0.141 \mathrm{lg} / \mathrm{g}$ dry weight (d.w.) $(\mathrm{Pb}$ in the bone/feather - rather than in the solution) per sample. Bone standard recovery was $103.2 \%$ (SD
12.32), (using bone meal standard SRM1486, Promochem Ltd., Herts, UK) and spike recovery was $87.99 \%$ (SD 16.08) (using certified $1000 \mathrm{lg} / \mathrm{g}$ standard solution).

Feathers were washed in running deionised water and then air dried prior to analysis. Bone/feather samples were weighed to an accuracy of $0.001 \mathrm{~g}$ into acid cleaned digest tubes. Digest solutions were stored in refrigerated conditions until analysis

Statistical tests were carried out using Minitab 13 statistical software.

\section{Results}

The distribution of bone lead concentrations $(\mathrm{PbB})$ is given in Fig. 1(a). The majority of birds $(n=30)$ had concentrations of well below $30 \mathrm{lg} / \mathrm{g}$ d.w. Four birds had $\mathrm{PbB}$ concentrations $>50 \mathrm{lg} / \mathrm{g}$ (Table 2), and had
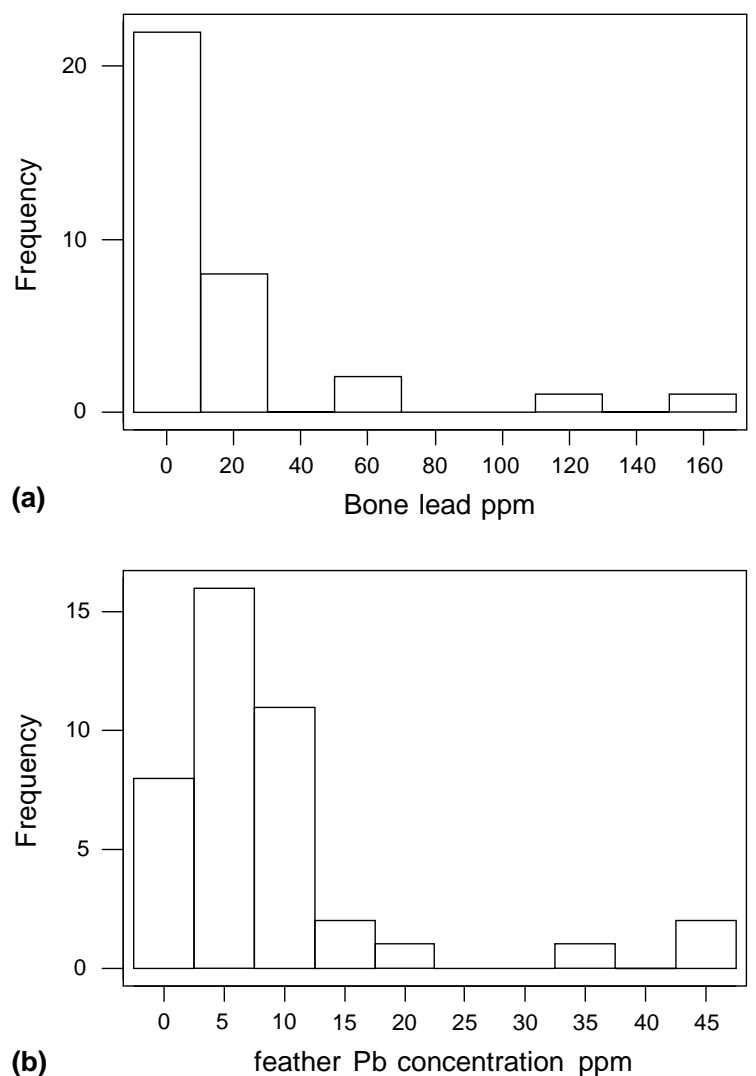

Fig. 1. Distribution of lead concentrations in Spanish imperial eagle femurs ((a) $n=34)$ and feathers $((b) n=41)$.

Table 2

Elevated bone lead concentrations in Spanish imperial eagles

\begin{tabular}{lllc}
\hline Age & Location & Cause of death & Bone lead lg/g d.w. \\
\hline Three years & Unknown & Unknown & 51.54 \\
Juvenile & Donana & Electrocuted & 56.26 \\
Chick & Donana & Shot & 114.65 \\
Juvenile & Malaga & Shot & 155.24 \\
\hline
\end{tabular}


been exposed to very high lead concentrations. These birds were collected in $1980(\mathrm{n}=1), 1983(\mathrm{n}=2)$ and $1990(\mathrm{n}=1)$. Bone lead concentrations did not follow a normal distribution, even when the outliers $>50 \mathrm{lg} / \mathrm{g}$ were excluded (Anderson Darling $\mathrm{A}^{2}=1.820, \mathrm{p}<$ 0.001). Feather $\mathrm{Pb}$ concentrations are given in Fig. 1(b). No birds had feather $\mathrm{Pb}$ concentrations $>50 \mathrm{lg} /$ $\mathrm{g}$, but three had concentrations of 30-50 lg/g. Feather lead distribution did not follow a normal distribution unless the three high outliers are excluded, when distribution was not significantly different from normal (Anderson Darling $\mathrm{A}^{2}=0.684, \mathrm{p}=0.07$ ).

To investigate the relationships between sample lead concentrations, bird age at death, and museum specimen age, we examined lead concentrations both with, and without obvious outliers to the distributions, as we suspected that the source of lead contributing to outliers may be different to that to which the majority of the population is exposed.

When all data were considered, significant correlations were found between bone lead and bird age at death, and feather lead and the length of time the specimen had been in the museum (specimen age- Table 3). The significance of these relationships increased on excluding outliers to the distributions (Table 3, Figs. 2 and 3).

Birds less than one year old $(\mathrm{n}=10$, median PbB 2.26) had significantly lower bone lead concentrations than those of one year or older $(\mathrm{n}=13$, median $\mathrm{PbB} 8.99$, Mann-Whitney, $\mathrm{U}=76.0, \mathrm{p}=0.007$ adjusted for ties).

For the ten birds where both bone and feather samples were analysed $\mathrm{PbB}$ concentrations ranged from 1.41 to $114.64 \mathrm{lg} / \mathrm{g}$ (with two greater then $50 \mathrm{lg} / \mathrm{g}$ ) and feather lead from $1.05-14.28 \mathrm{Ig} / \mathrm{g}$. Bone and feather lead concentrations were not correlated (Pearson correlation coefficient $=0.341$, Pz-value $=0.334, n=10$ ).

\section{Discussion}

\subsection{Lead in bones}

Bone lead has a long half-life (600-3000 days in human bone, Harrison and Laxen, 1981); consequently a relationship between age and bone lead is expected, excepting cases of acute exposure (Fig. 2). Other authors have similarly found bone lead concentrations to be positively correlated with age in waterfowl populations (Stendell et al., 1979; Clausen et al., 1982). However, bone lead concen-

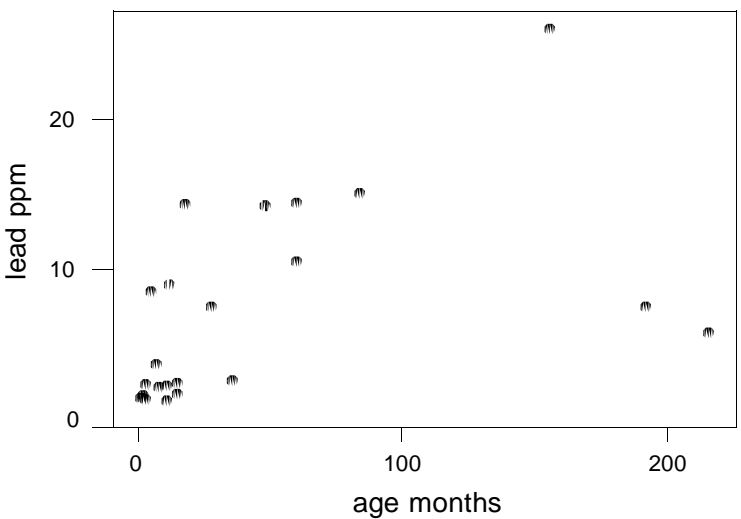

Fig. 2. The relationship between bone lead and age in Spanish Imperial Eagles after the removal of outliers with $>50 \mathrm{lg} / \mathrm{g} \mathrm{d.w}$.

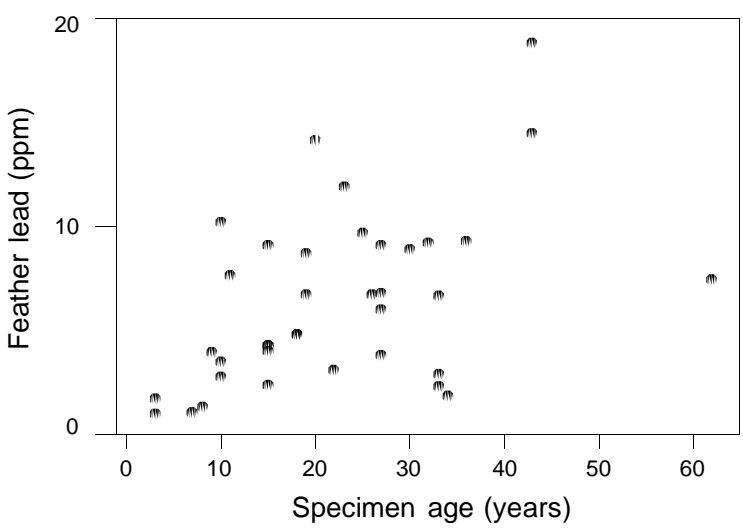

Fig. 3. The relationship between age of museum specimens and feather lead concentrations after the removal of outliers with $>30 \mathrm{lg} /$ g d.w.

trations may be difficult to interpret in individual birds. Although lead has a high affinity for bone, birds acutely exposed to lead may die with very elevated soft tissue concentrations, but before much lead has been deposited in bone. For example, Pattee et al. (1981) reported that bald eagles $\mathrm{H}$. leucocephalus experimentally exposed to lead shot, died with mean lead residues of $17 \mathrm{lg} / \mathrm{g}$ in the liver, but only $10 \mathrm{lg} / \mathrm{g}$ in bone. Conversely, birds may accumulate a certain amount of lead in the bone over their lifetimes from chronic and non-lethal acute exposure, with few signs of toxicity. The genus, behaviour and environment of birds must also be taken into account when interpreting $\mathrm{PbB}$; free-living birds of prey generally have lower $\mathrm{PbB}$ concentrations than waterfowl (e.g., see Clark and Scheuhammer, 2003).

Table 3

Relationship between bone lead or feather lead, age of bird at death and age of museum specimen

\begin{tabular}{lllll}
\hline & $\begin{array}{l}\text { Bone lead } \\
\text { All data }\end{array}$ & Excluding outliers & $\begin{array}{l}\text { Feather lead } \\
\text { All data }\end{array}$ & Excluding outliers \\
\hline $\begin{array}{l}\text { Bird age at death } \\
\text { Museum specimen age }\end{array}$ & $\mathrm{R}=0.507, \mathrm{p}=0.007, \mathrm{n}=27$ & $\mathrm{R}=0.666, \mathrm{p}=0.001, \mathrm{n}=23$ & $\mathrm{R}=0.269, \mathrm{p}=0.280, \mathrm{n}=18$ & $\mathrm{R}=0.269, \mathrm{p}=0.280, \mathrm{n}=18$ \\
& $\mathrm{R}=0.096, \mathrm{p}=0.628, \mathrm{n}=28$ & $\mathrm{R}=-0.114, \mathrm{p}=0.596, \mathrm{n}=24$ & $\mathrm{R}=0.412, \mathrm{p}=0.008, \mathrm{n}=40$ & $\mathrm{R}=0.464, \mathrm{p}=0.004, \mathrm{n}=37$ \\
\hline
\end{tabular}

Spearman rank correlation. Outliers excluded were $>50 \mathrm{lg} / \mathrm{g}$ bone lead, $>30 \mathrm{lg} / \mathrm{g}$ feather lead (Figs. 1(a) and (b)). 
In waterfowl, bone lead concentrations of $>20 \mathrm{lg} / \mathrm{g}$ are considered to be associated with excessive exposure to and absorption of $\mathrm{Pb}$; birds that have died of lead poisoning often have bone lead concentrations in excess of 20-30 lg/g (Pain, 1996; Franson, 1996). Having data for a number of birds from a population helps in $\mathrm{PbB}$ interpretation, as we can examine the $\mathrm{PbB}$ distribution and identify outliers that may suggest a different source of exposure. Our results from Spanish imperial eagles suggest that the four birds with $\mathrm{PbB}$ of $51-155 \mathrm{Ig} / \mathrm{g}$ had been exposed to very high lead concentrations (Fig. 1). As all of these birds were young (a chick, two juveniles and a three year old), this results from acute rather than chronic exposure. Young Spanish imperial eagles tend to have $\mathrm{PbB}$ of at least an order of magnitude lower than these four birds (Fig. 2; $2.26 \mathrm{lg} / \mathrm{g}$ for birds $<1$ year old). We consider the obvious source of $\mathrm{Pb}$ exposure for the 4 contaminated birds to be the ingestion of lead gunshot in their prey. The two highest bone lead concentrations were from shot birds. However, it is highly improbable that bone samples would have been contaminated with lead fragments from shot-in gunshot as bone samples were extracted from the femurs, bones were cleaned of all soft tissue when the museum specimens were prepared, and soft lead fragments will not have penetrated bone samples.

Hundreds of thousands of waterfowl winter in Doñana annually (Hiraldo et al., 1991), including greylag geese Anser anser (Persson, 1993), which are heavily hunted as they move between their northern European breeding grounds and wintering grounds in Southern Spain. For example, in the winter of 1983/84 ca. 120,000 greylag geese wintered in southern Spain; over the same period an estimated 16,000 birds were shot in France, largely during spring migration (Yésou, 1987; Persson, 1999). Not all shot birds die, e.g. in the USA an estimated $15 \%$ to $25 \%$ of shot birds may be injured but escape, or killed but unretreived (Morehouse, 1992). In free-living waterfowl the prevalence of embedded shot can range from 10 to $68 \%$ (Scheuhammer and Norris, 1996) and Calderón et al. (1996) found that 66\% of greylag geese found dead in Doñana had embedded shot in their flesh. In winter, the diet of Spanish imperial eagles largely consists of waterfowl (about 47\%, Mateo et al., 2001), mainly greylag geese (González, 1991; Ferrer, 2001), including scavenged dead birds (Hiraldo et al., 1991). Mateo et al. (2001) recorded lead shot in $11 \%$ of Spanish imperial eagle regurgitated pellets from Doñana, confirming exposure to lead, and Hernández (1995) reported an obvious clinical case of lead poisoning in a Spanish imperial eagle. All birds that ingest lead shot will absorb some lead before regurgitation, and whilst shot ingestion will not always result in lead poisoning, results from studies on a wide range of raptors indicate that a proportion of birds ingesting shot will develop lead poisoning (Table 1 ). This proportion may vary according to the retention time of shot before regurgitation, the frequency of exposure, and perhaps other, dietary or metabolic, factors. Pain et al. (1993) found that in the marsh harrier Circus aeruginosus in western France, 12\% of 214 regurgitated pellets contained at least one lead shot, whilst $>30 \%$ of 31 birds had elevated $(>30 \mathrm{lg} / \mathrm{dl})$ blood lead concentrations, $9 \%$ of which were very elevated $(>60 \mathrm{lg} / \mathrm{dl})$ and indicative of lead poisoning. We do not know if similar relationships hold for other species, but this gives an indication of the potential for lead poisoning in the Spanish imperial eagle.

Our results show that $12 \%$ of the Spanish imperial eagles sampled over a 20 -year period had absorbed very elevated lead concentrations, most likely due to ingesting lead shot. This does not reflect the proportion of the population that dies of lead poisoning, as our sample was of birds that had died from a variety of known and unknown causes. Of the birds with elevated bone lead (Table 2), $\mathrm{Pb}$ is unlikely to have been a contributory factor in the mortality of the electrocuted bird, but could have been the cause of death of the individual with no known cause of mortality. Of the two birds shot, bone lead concentrations were so elevated that the chick will have been acutely exposed and the juvenile was probably acutely exposed; both may have been suffering from lead poisoning when shot. $\mathrm{Pb}$ could have contributed directly to the mortality of the shot juvenile, as poisoned birds are weak and thus may make easier targets.

\subsection{Lead in feathers}

Lead in feathers has two origins. Endogenously incorporated $\mathrm{Pb}$ reflects that in blood at the time of feather formation (Burger, 1993; Denneman and Douben, 1993), thus could provide an indicator of $\mathrm{Pb}$ contamination over a relatively short period. Exogenous $\mathrm{Pb}$, deposited from the atmosphere on the feather between formation and sampling or moult, can provide an indicator of local atmospheric contamination for sedentary species (Dauwe et al., 2002). In addition, contaminants can be deposited on feathers during preening (Goede and de Bruin, 1984). Discrimination between endogenous and exogenous $\mathrm{Pb}$ usually involves cleaning, and methods have variable success (Niecke et al., 1999; Burger, 1994). The correlation that we found between feather lead concentrations and the age of specimens (after omission of high outliers) suggests that much of the lead is exogenous in origin, having being deposited from the atmosphere following specimen collection. As with other studies, this suggests that feathers could be used to indicate local atmospheric contamination (Burger, 1993; Dauwe et al., 2002). In our samples, it was relatively easy to separate outliers, presumably due to high endogenous incorporation of lead following acute exposure, probably from shot ingestion. 
Lead appears in bones rapidly following exposure and absorption (Sanderson and Bellrose, 1986), and is retained long-term (Harrison and Laxen, 1981); $\mathrm{PbB}$ concentrations reflect acute and chronic exposure. It is likely, therefore, that a higher proportion of birds will have elevated bone than feather lead, and that the two will only be correlated in individuals if acute exposure events occur during feather formation. The relationship between feather and bone lead is further complicated when museum specimens of varying age are used, as bone lead remain stable, but feather lead increases over time in museum specimens. Our findings show seven percent of feathers, and $12 \%$ of bone samples to be high outliers to the lead distributions. Two of ten bone samples had $\mathrm{PbB}$ concentrations $>50 \mathrm{Ig} / \mathrm{g}$, but neither of these individuals had feather $\mathrm{Pb}>15 \mathrm{lg} / \mathrm{g}$, suggesting that elevated exposure to lead did not take place during feather formation. We suggest that feather lead is less useful than bone lead as a measure of lead absorption in birds, both because feather lead originates from blood lead over the relatively short time period of feather formation, and because of the need to separate lead of endogenous and exogenous origins. However, if exogenously deposited lead can be reliably removed, the utility of feathers will be improved.

\subsection{Conservation measures}

Lead poisoning in raptors is not new - there has been evidence of lead poisoning mortality in bald eagles from gunshot ingestion, and Californian condors from the ingestion of bullet fragments, for decades in the USA (Pattee and Hennes, 1983; Wiemeyer et al., 1986, 1988). However, as more research has been conducted, an increasing body of evidence of lead poisoning in other species has accumulated. The victims include several threatened species, within and outside Europe (Table 1). Unlike the Californian condor, lead poisoning is not the major threat to the Spanish imperial eagle population. However, it does present an unnecessary threat to adult birds, and in this small, globally threatened and declining population action should be taken to avoid any preventable additional mortality.

This problem has a technically, if not politically, simple solution - the use of alternative non-toxic materials to replace lead. As of 2000, twenty countries have had total or partial statutory bans on the use of lead gunshot for waterfowl hunting (Beintema, 2000); steel shot is widely used in the USA and other countries, and other alternatives are commercially available (e.g., bismuth and tin; Beintema, 2000).

A variety of Conventions, Directives and Agreements address the lead poisoning issue directly or indirectly, including the 79/409/EEC Directive on the Conservation of Wild Birds, the RAMSAR Convention on Wetlands of International Importance the African eurasian migra- tory waterfowl agreement (AEWA), under the Bonn Convention. However, these deal the use of lead shot for either the hunting of waterfowl, or hunting over wetlands. Whilst a Europe-wide ban on such uses would certainly reduce the lead poisoning risk to Spanish imperial eagles and other raptors, it would not eliminate it. Greylag geese use a variety of habitats including both wetlands and agricultural land, and many raptors may be exposed to shot in a variety of non-waterfowl game, from rabbits to pigeons (Table 1).

Spain itself has a partial ban on the use of lead, but this will not stop predatory and scavenging raptors from dying of lead poisoning following the ingestion of migratory species, carrying shot from elsewhere. As recommended in Beintema (2000), countries should be encouraged to sign relevant international biodiversity conventions and agreements, and, once signed, should be held responsible for their action regarding issues addressed by the conventions. Even in countries with statutory bans on the use of lead enforcement is often lacking, and is urgently required. There is also a need for increased awareness of the problem, both for waterfowl and other avian taxa, especially threatened species. This, along with improved communication and cooperation between legislative authorities and hunting organisations is necessary before an effective ban on the use of lead shot is likely.

The more scientific research that is conducted, the more species are found to either suffer lead poisoning, or be at risk of lead poisoning, through lead shot ingestion. This includes a number of threatened and declining species, such as the Spanish imperial eagle (Mateo et al., 2001; Hernández, 1995; this study), whose already declining populations could be further impacted by lead poisoning. The only way to eliminate this source of mortality is to ban all hunting with lead, not simply waterfowl hunting.

\section{Acknowledgements}

We thank the museum of Doñana Biological Station; especially Dr. J. Cabot for allowing us to take samples, J. Balbontín, and J. Ayala for their help in taking samples. Thanks to the RSPB for funding this study, and David Gibbons and John O'Sullivan for commenting on the manuscript.

\section{References}

Bellrose, F.C., 1959. Lead poisoning as a mortality factor in waterfowl populations. Illinois Natural History Survey Bulletin 27, 235-288.

Benson, W.W., Pharoah, B., Miller, P., 1974. Lead poisoning in a raptor. Bulletin of Environmental Contamination and Toxicology 11, 105-108.

Beintema, N., 2000. Lead Poisoning in Waterbirds: International Update Report 2000. Wetlands International, Wageningen Pp. 76. 
BirdLife International, 2000. Threatened Birds of the World. Lynx Ediciones, Barcelona and BirdLife International, Cambridge.

Bloom, P.H., Scott, J.M., Pattee, O.H., Smith, M.R., 1989. Lead contamination of Golden Eagles Aquila chrysaetos within the range of the Californian Condor Gymnogyps californianus. In: Meyburg, B.-U., Chancellor, R.D. (Eds), Raptors in the Modern World. World Working Group on Birds of Prey, Berlin, London and Paris.

Burger, J., 1993. Metals in avian feathers: bioindicators of environmental pollution. Reviews in Environmental Toxicology 5, 203311.

Burger, J., 1994. Metals in avian feathers: bioindicators of environmental pollution. Reviews in Environmental Toxicology 5, 521530.

Calderón, J., Ramo, C., Chans, J.J., García, L., 1996. Plan de gestión cinegética para el ánsar común en las Marismas del Guadalquivir. Estación Biológica de Doñana, Huelva.

Clark, A.J., Scheuhammer, A.M., 2003. Lead poisoning in uplandforaging birds of prey in Canada. Ecotoxicology 12, 23-30.

Clausen, B., Elvestad, K., Karlog, O., 1982. Lead burden in mute swans from Denmark. Nordisk Veterinaermedicin 34, 83-91.

Dauwe, T., Bervoets, L., Blust, R., Eens, M., 2002. Tissue levels of lead in experimentally dosed zebra finches (Taeniopygia guttata) with particular attention on the use of feathers a s biomonitors. Archives of Environmental Contamination and Toxicology 42, 88-92.

Dauwe, T., Bervoets, L., Pinxten, R., Blust, R., Eens, M., 2003. Variation in heavy metals within and among feathers of birds of prey: effects of moult and external contamination. Environmental Pollution 124, 429-436.

Denneman, W.D., Douben, P.E.T., 1993. Trace metals in primary feathers of the barn owl (Tyto alba guttattus) in the Netherlands. Environmental Pollution 82, 301-310.

Ferrer, M., 2001. The Spanish Imperial Eagle. Lynx Editions, Barcelona, Spain.

Ferrer, M., Calderón, J., 1990. The Spanish Imperial Eagle Aquila adalberti in Doñana National Park: a study of population dynamics. Biological Conservation 51, 151-161.

Ferrer, M., Donázar, J.A., 1996. Density-dependent fecundity by habitat heterogeneity in an increasing population of Spanish imperial eagles. Ecology 77, 69-74.

Ferrer, M., Penteriani, V., Balbontín, J., Pandolfi, M., 2003. The proportion of immature breeders as a reliable early warning signal of population decline: evidence from the Spanish Imperial Eagle in Doñana. Biological Conservation 114, 463-466.

Franson, J.C., 1996. Interpretation of tissue lead residues in birds other than waterfowl. In: Beyer, W.N., Heinz, G.H., RedmonNorwood, A.W. (Eds.), Environmental Contaminants in Wildlife: Interpreting Tissue Concentrations. SETAC, Special Publication Series, CRC Lewis Publishers, Boca Raton, CA, pp. 265-279.

Franson, J.C., Thomas, N.J., Smith, M.R., Robbins, A.H., Newman, S., McCartin, P.C., 1996. A retrospective study of post-mortem findings in red-tailed hawks. Journal of Raptor Research 30 (1), 714.

Goede, A.A., de Bruin, M., 1984. The use of bird feathers as a monitor for metal pollution. Environmental Pollution B 8, 281-298.

González, 1.M., 1991. Historia Natural del águila imperial ibérica (Aquila adalberti Brehm, 1981). Instituto Nacional para la Conservación de la Naturaleza, Madrid.

Harrison, R.M., Laxen, D.P.H., 1981. Lead Pollution: Causes and Control. Chapman Hall, London.

Hernández, M., 1995. Lead poisoning in a free-ranging imperial eagle. Supplement Journal of Wildlife Diseases 31 (newsletter).

Hiraldo, F., Blanco, J.C., Bustamante, J., 1991. Unspecialized exploitation of small carcasses by birds. Bird Study 38, 200-207.

Kim, E.Y., Goto, R., Iwata, H., Masuda, Y., Tanabe, S., Fujita, S., 1999. Preliminary survey of lead poisoning of Steller's sea eagle (Haliaeetus pelagicus) and white-tailed sea-eagle (Haliaeetus albi- cilla) in Hokkaido, Japan. Environmnetal Toxicology and Chemistry $18,448-451$.

Kenntner, N., Tataruch, F., Krone, O., 2001. Heavy metals in soft tissues of white-tailed eagles found dead or moribund in Germany and Austria from 1993 to 2000. Environmental Toxicology and Chemistry 20 (8), 1831-1837.

Kenntner, N., Krone, O., Altenkamp, R., Tataruch, F., 2003. Environmental contaminants in liver and kidney of free-ranging northern goshawks (Accipiter gentilis) from three regions of Germany. Archives of Environmental Contamination and Toxicology 45 (1), 128-135.

Kurosawa, N., 2000. Lead poisoning in Steller's Sea Eagles and Whitetailed Sea Eagles, pp. 107-109. In: Ueta, M., McGrady M. J. (Eds.), First Symposium on Steller's and White-tailed Sea Eagles in East Asia. Proceedings of the International Workshop and Symposium in Tokyo and Hokkaido, 9-15 February 1999. Wild Bird Society of Japan, Tokyo.

Mateo, R., Molina, R., Grifols, J., Guitart, R., 1997. Lead poisoning in a free ranging griffon vulture Gyps fulvus. The Veterinary Record $140,47-48$.

Mateo, R., Cadenas, R., Máñez, M., Guitart, R., 2001. Lead shot ingestion in two raptor species from Doñana, Spain. Ecotoxicology and Environmental Safety 48, 6-10.

Mateo, R., Taggart, M., Meharg, A.A., 2003. Lead and arsenic in bones of birds of prey from Spain. Environmental Pollution 126, 107-114.

Mateo, R., Estrada, J., Paquet, J.Y., Riera, X., Dominguez, L., Guitart, R., Martinez-Vilalta, A., 1999. Lead shot ingestion by marsh harriers Circus aeruginosus from the Ebro delta, Spain. Environmental Pollution 104 (3), 435-440.

Miller, M.J.R., Wayland, M.E., Bortolotti, G.R., 2001. Exposure of migrant bald eagles to lead in prairie Canada. Environmental Pollution 112 (2), 153-162.

Morehouse, K., 1992. Crippling loss and shot type: the United States experience, pp. 32-37. In: Pain, D.J. (Ed.), Lead poisoning in waterfowl. Proceedings of an IWRB Workshop, Brussels, Belgium. June 1991. IWRB Special Publication No. 16. Slimbridge, UK, p. 105.

Niecke, M., Heid, M., Krüger, A., 1999. Correlations between melanin pigmentation and element concentration in feathers of White-tailed eagles (Haliaeetus albicilla). Journal für Ornithologie 140, 355-362.

Pain, D.J., 1995. Lead in the Environment (Chapter 16, pp. 356-391). In: Hoffman, D.J., Rattner, B.A., Allen Burton, G. Jr. Cairns, J. Jr. (Eds.), Handbook of Ecotoxicology. CRC Press, Lewis Publishers USA, p. 755.

Pain, D.J., 1996. Lead in Waterfowl (Chapter 10, pp. 251-264). In: Beyer, W.N., Heinz G.H., Redmon A.W. (Eds.) Environmental Contaminants in Wildlife: Interpreting Tissue Concentrations. SETAC, Special Publication Series, CRC Lewis Publishers, Boca Raton.

Pain, D.J., Amiard-Triquet, C., 1993. Lead poisoning of raptors in France and elsewhere. Ecotoxicology and Environmental Safety 25, 183-192.

Pain, D.J., Amiard-Triquet, C., Bavoux, C., Burneleau, G., Eon, L., Nicolau-Guillaumet, P., 1993. Lead poisoning in wild populations of marsh harriers Circus aeruginosus in the Camargue and Charente-Maritime, France. IBIS 135, 379-386.

Pain, D.J., Sears, J., Newton, I., 1995. Lead concentrations in birds of prey in Britain. Environmental Pollution 87 (2), 173-180.

Pain, D.J., Bavoux, C., Burneleau, G., 1997. Seasonal blood lead concentrations in marsh harriers Circus aeruginosus from Charente-Maritime, France: relationship with the hunting season. Biological Conservation 81, 1-7.

Pattee, O.H., Hennes, S.K., 1983. Bald eagles and waterfowl: the lead shot connection. In: 48th North American Wildlife Conference. The Wildlife Management Institute, Washington, DC. 
Pattee, O., Weimeyer, S.N., Mulhern, B.M., Sileo, L., Carpenter, J.W., 1981. Experimental lead shot poisoning in bald eagles. Journal of Wildlife Management 45, 806-810.

Persson, H., 1993. Arrival patterns of greylag geese Anser anser in the Guadelquivir marshes. Wildfowl 44, 19-23.

Persson, H., 1999. Le chasse a L'oie cindrée Anser anser en France - ou de l'exploitation excessive d'une resource naturelle. Alauda 67 (3), 223-230.

Sanderson, G.C., Bellrose, F.C., 1986. A review of the problem of lead poisoning in waterfowl. Illinois Natural History Survey Special Publication No. 4, Illinois.

Scheuhammer, A.M., Norris, S.L., 1996. The ecotoxicology of lead shot and lead fishing weights. Ecotoxicology 5, 279-295.

Stendell, R.C., Smith, R.I., Burnham, K.P., Christensen, R.E., 1979. Exposure of waterfowl to lead: a nationwide survey of residues in wingbones of seven species, 1972-1973. US Fish and Wildlife Service Special Scientific Report Wildlife, vol. 223, pp. 1-12.
USFWS, 1986. Use of lead shot for hunting migratory birds in the United States. Final supplement environmental impact statement. Department of the Interior, Fish and Wildlife Service. Government Printing Office, Washington, DC.

Wayland, M., Wislon, L.K., Elliott, J.E., Miler, M.J.R., Bollinger, T., McAdie, M., Langelier, K., Keating, J., Froese, J.M.W., 2003. Mortality, morbidity and lead poisoning of eagles in western Canada 1986-1998. Journal of Raptor Research 37 (1), 8-18.

Wiemeyer, S.N., Jurek, R.M., Moore, J.F., 1986. Environmental contaminants in surrogates, foods, and feathers of Californian condors (Gymnogyps californianus). Environmental Monitoring and Assessment 6, 91-111.

Wiemeyer, S.N., Scott, J.M., Anderson, M.P., Bloom, P.H., Stafford, C.J., 1988. Environmental contaminants in California condors. Journal of Wildlife Management 52, 238-247.

Yésou, P., 1987. La chasse aux oies (Anser sp) en France: une première analyse du prélèvement. Bulletin Mensuel de l'Office National de la Chasse 109, 7-13. 